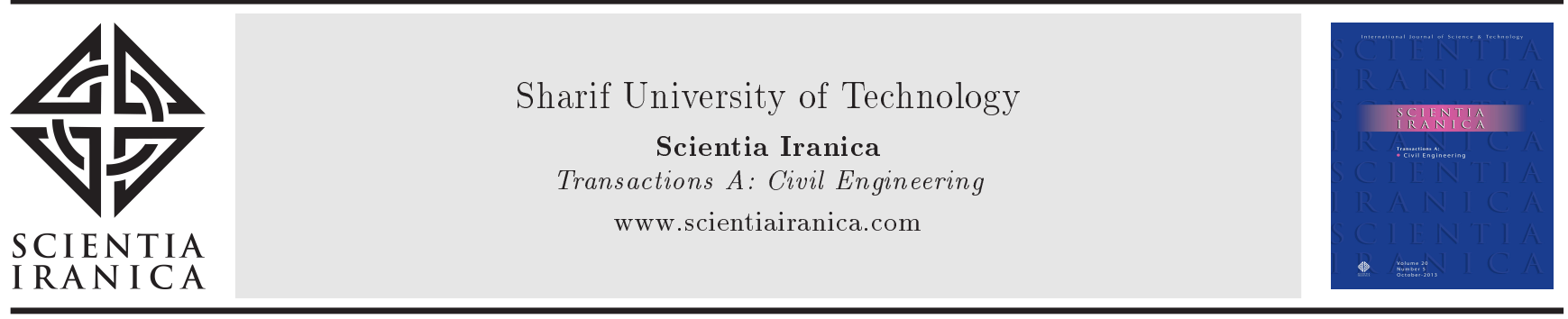

\title{
The role of geotechnical engineering in sustainable and resilient cities
}

\author{
S.M. Haeri* \\ Department of Civil Engineering, Sharif University of Technology, Tehran, Iran. \\ Received 17 May 2015; received in revised form 12 August 2015; accepted 18 October 2015
}

\section{KEYWORDS \\ Geotechnical; \\ Engineering; \\ Sustainable; \\ Resilient; \\ Cities.}

\begin{abstract}
Geotechnical engineering is a fundamental subject in civil and environmental engineering that engineers are required to refer to when any type of retrofitting, design or construction of projects and developments are encountered in a city or in a rural area. Indeed in many projects like geotechnical structures, such as earth dams, geotechnical engineering is the main subject. In this paper, the role of geotechnical engineering in sustainable and resilient cities is elaborated mainly through a series of questions and answers. Also, some related geotechnical engineering research, that is in hands in Civil Engineering Department of Sharif University, is discussed in this paper. A unique geotechnical engineering project that is designed and supervised in the city of Tehran by the author is also introduced herein to indicate how an accurate design and construction of a geotechnical structure can result in a sustainable and resilient condition. However, due to the variety of the subjects involved under the title of the paper, some of the subjects are touched briefly.
\end{abstract}

(C) 2016 Sharif University of Technology. All rights reserved.

\section{Introduction}

When a development town or city is under planning, the following questions should be answered properly before any action is taken, in order to have a sustainable and resilient city or development, at least from stability point of view:

- Can we do any development on or in the earth without looking at geotechnical engineering?

- A requirement implies that we study whether the ground withstands such loading for any development on or in the ground.

- If the ground withstands, is the associated ground displacement acceptable for the planned development or structures?

\footnotetext{
*. Tel.: +982166164230; Fax: +982166014828

E-mail address: smhaeri@sharif.edu
}

- Is the associated displacement acceptable for the surrounding area of the planned structures, including building, roads, etc.?

The prerequisite for answering all above questions is to perform appropriate geotechnical investigation and evaluate the results, implementing engineering judgment, in a way that the required geotechnical parameters could be extracted and utilized in the design of foundations of the structures or any other developments. Without performing the required geotechnical studies for any kind of construction, no sustainable or resilient development can be foreseen.

Developments can be any type of construction such as: Construction of new cities, towns or villages, roads and bridges, tunnels and underground facilities, marine structures, buildings and towers, dams, etc., or extending the existing ones

When a development is being planned, the developer needs to study if the ground can withstand safely 
the loadings associated with such a development during construction and operation period. For this purpose, the following questions should be answered:

- Is the ground made of soft soils having long term settlement?

- Is the ground made of problematic soils such as collapsible or swelling soils? And if the answer is positive, how this problem can be treated?

- Is it worth to build or develop on such soils spending time and money for remedial measures, or find an alternative place?

- Is the development on sloping ground? Is it safe to build on that ground? What are the consequences?

- Is the development located in an earthquake prone area? Is it safe to build on that ground? What are the consequences?

In the following sections, some of the above points are touched and some are detailed to clarify why geotechnical engineering is so important for having sustainable or resilient city.

\section{Problematic soils}

There are many types of problematic soils such as swelling soils, collapsible soils, very soft or quick clays, liquefiable soils, meta-stable soils, etc. If these kinds of soils are involved in a project, the engineer or the client should consult with an expert in geotechnical engineering to find appropriate solutions for that problematic ground. The problems involved with liquefiable soils will be discussed in detail in Section 5. The main problems involved with very soft or quick clays are large and long term primary and secondary consolidation settlements, which are usually intolerable for structures if they are not studied and designed according to the soil characteristics. In addition, having very low or loss of shear strength of very soft or quick clays, respectively, are the problems that these soils are encountered, which may result in different types of failure modes [1-7]. Swelling is a destructive characteristic for a problematic soil and may damage the roads, irrigation canals, buildings and any development that is constructed on this type of soil. The swelling soil expands when it is subjected to wetting and either the heave of the ground surface happens or the ground exerts heavy uplift pressures on the foundation of the structures. The heave is usually uneven with differential displacements of the ground resulting in cracks and damages to the buildings and structures, and the latter may end up to damage in or failure of the structures if such loading is ignored in design process [8-12].

Meta-stable soils are mainly mixed soils, consisting of gravel and fines with little sand size grains and are generally gap graded with a framework that might be stable in natural condition. However, when this type of soil is subjected to a small loading or seepage, its structure brakes down and large displacement or soil migration may occur [13-21]. Ironic to swelling soils, collapsible soils such as loess experience collapse or sudden excessive settlements when they are subjected to wetting [22-32]. Many cities, irrigation canals, dam sites, roads and other developments in Iran and in the world are constructed on this type soil. For example, the city of Gorgan, the capital of Golestan province in North-east of Iran, is located on a collapsible loess. There are many damages and failures of the buildings and infrastructures of this city which can be attributed to the soil characteristics. A comprehensive investigation on collapse behavior of Gorgan loess has been underway for a decade at Advanced Soil Mechanics Laboratory of Sharif University of Technology (SUT) to address this problem. A small fraction of the investigations performed on this soil is detailed in the preceding section.

\subsection{Collapsible soils}

The tested collapsible soil is a type of loess taken from Hezarpich Hills in the city of Gorgan by undisturbed sampling. Loess is an aeolian deposit, composed mainly of silt size particles that are deposited in a windblown environment with an open structure and bonded with different types of bonding, depending on the environment of the formation. The texture of the tested collapsible loess is shown in SEM photos taken in different scales and illustrated in Figure 1 in which the open structure and large and heterogeneous voids are obvious. If this kind of soil is subjected to wetting, under some loadings, the soil will collapse, resulting in heavy damage to any structure that is built on top of that type of soil. Although comprehensive studies on the behavior of this soil is ongoing for a decade at SUT (e.g. [33-45]), only the result of a double oedometer test conducted on undisturbed specimens of the Gorgan loess for studying the response of this kind of collapsible soil to the loading and wetting is shown in Figure 2 [1]. In this figure, the amount of collapse in different inundation pressure is illustrated. Structures cannot withstand such a soil collapses or sudden excessive settlements, and sustainability or resiliency cannot be achieved if appropriate geotechnical investigation and design are not foreseen for developments on this type of soil. Remedial measures are needed to improve such a condition; however, this subject is not covered in this paper and the reader can refer to [41-44].

\section{Slope instability}

Slope instability is another geohazard that jeopardizes the sustainability and resiliency of the cities especially 


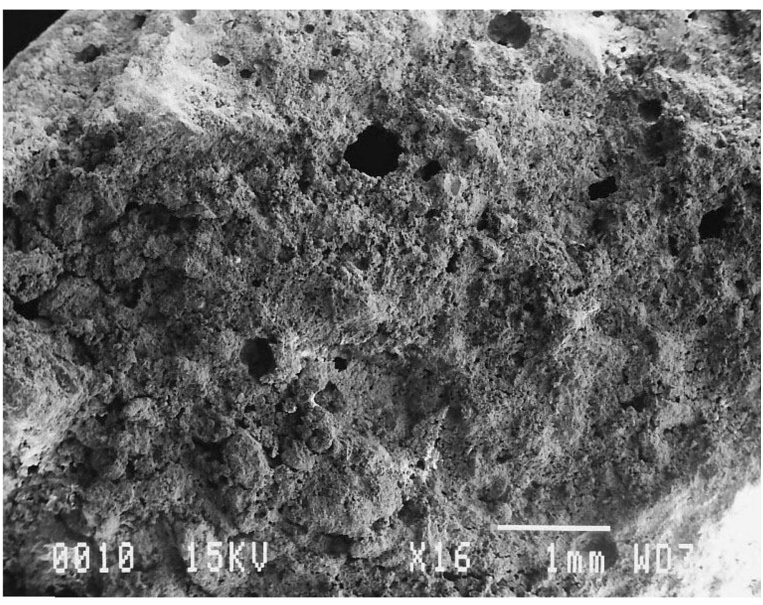

(a)

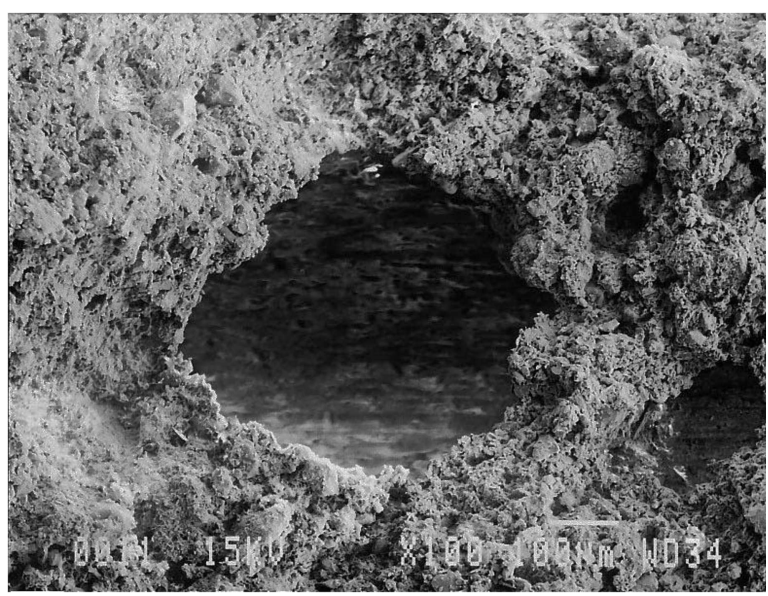

(b)

Figure 1. SEM photos of the tested collapsible loess structure at different scales: $(a)$ Enlargement $\times 16$; and (b) enlargement $\times 100$.

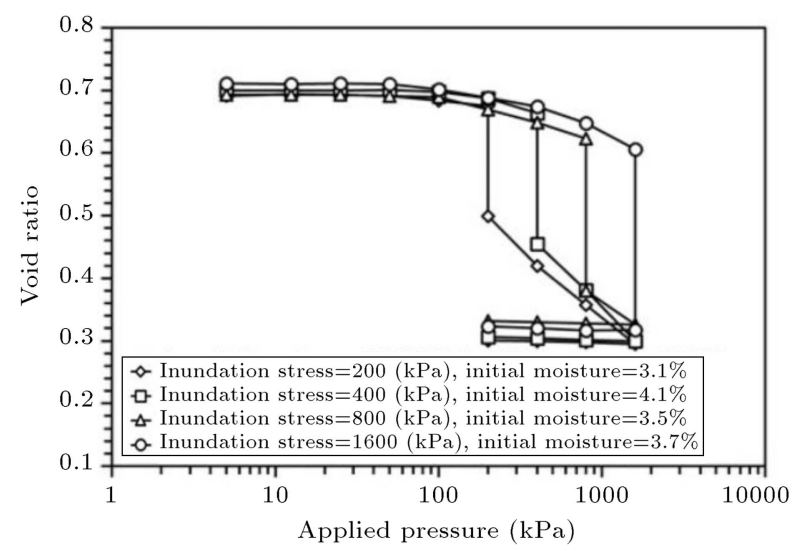

Figure 2. Double oedometer collapse test for undisturbed loess specimens [33].

in cases that are located on hill slopes or in mountainous area. There are two types of geohazard associated with slope instabilities: Natural and man-made. The natural instabilities of slopes or landslides are usually caused by heavy rainfalls or earthquakes. There are many examples of landslides induced by heavy rain falls and subsequent flooding in the world. Recent landslides in Pakistan, Brazil, Costa Rica, etc. are some of many destructive landslides that have been taken place due to excessive rainfalls. General failure, mudflow and rockslide are the most common modes of failure in this respect. Earthquake induced landslides are another type of natural instability of slopes and can be very destructive. Manjil (Iran, 1990) and Niigata (Japan, 2004) are two examples of heavily destructive cases. Taking lesson from the past dictates the fact that for sustainable and resilient cities and developments geological and geotechnical studies with respect to the possibility of landslide should be in hands for site selection. If the risk of construction in sloping ground is very high and the site cannot be dislocated, the types and details of preemptive measures to guarantee lifetime safety and sustainability of the development should be investigated. It is evident that the cost, time and acceptable risks play a decisive role on the final design.

Man-made slope instabilities are generally associated with excavation of the toe of slopes to prepare enough room for executing a project, mainly roads. This type of intrusion in the slopes without a comprehensive geological and geotechnical study and design commonly results in instability. Generally in normal and dry conditions the slopes may stay stable; however, heavy rain or earthquake usually trigger instability in such slopes which may end to a disaster. There are many evidences for this type of failure; Tehran-Rasht and Tehran-Chalus freeways are two recent examples in Iran. Two photos from landslides that resulted in a relatively long time closure of part 4 of Tehran-Chalus freeway are shown in Figure 3(a), and (b).

Design and construction of the roads are mainly without an appropriate geotechnical study. As a result, during construction or service of the road, many problems including slope instability arise. The time and money spent to rectify the problem is usually 12 folds more than the cost of design and construction based on geotechnical studies. Therefore sustainability and resiliency cannot be expected for a project if appropriate geotechnical studies and design are not foreseen in a road construction in mountainous area with plenty of slopes. The landslide shown in Figure 3(a) has damaged the old road tunnel support, the retaining system of the excavation for the new freeway and blocked the traffic passage in TehranChalus freeway, after a heavy rain. Also the landslide illustrated in Figure 3(b) has damaged the buildings far from the freeway, the retaining system of the excavation for constructing the freeway, and blocked the traffic passage in Tehran-Chalus freeway just after a heavy rain. The debris has been cleaned away temporarily for operation of freeway. 


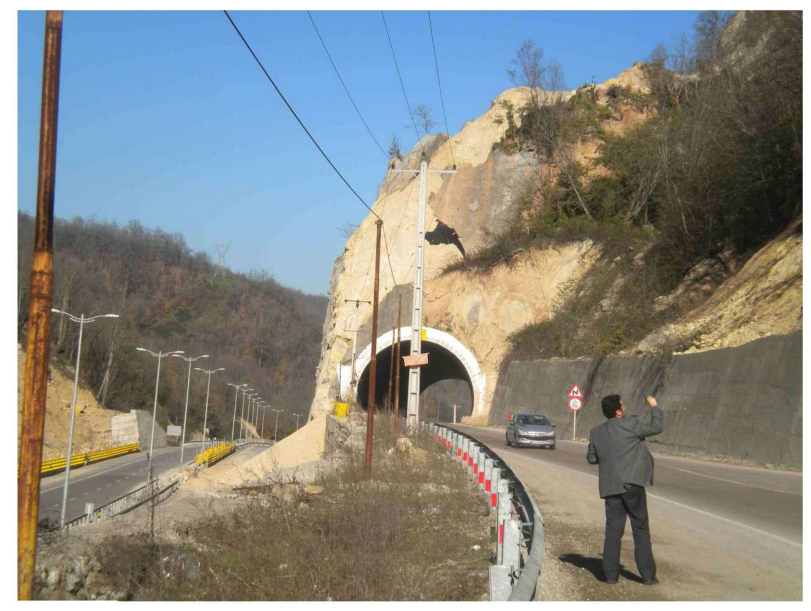

(a)

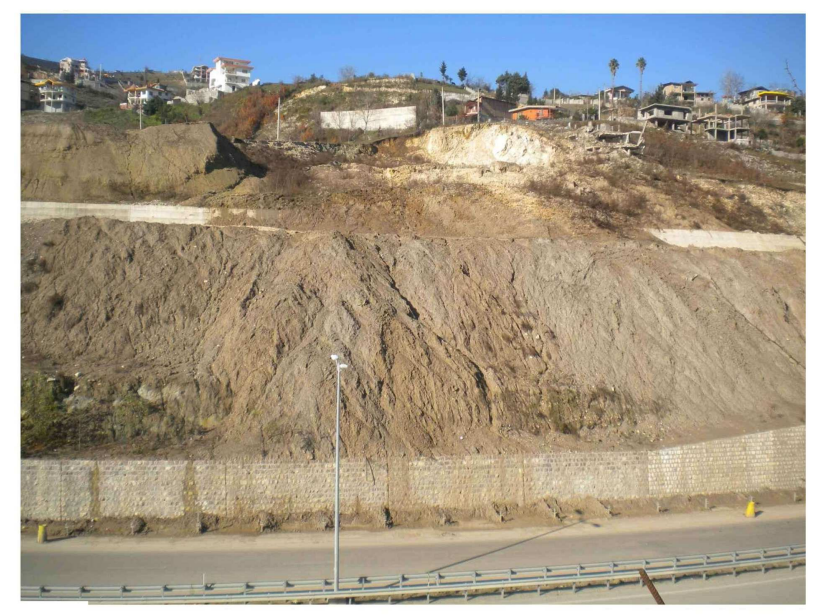

(b)

Figure 3. a) The landslide over one of the tunnels of the old Tehran-Chalus road due to excavation for new highway. b) A deep and huge landslide in western wing of Tehran-Chalus highway.

\section{Deep excavation}

Deep excavation for high rise buildings in developing cities is a very special and delicate task with a prerequisite of special geotechnical study and design by experts in this subject. Due to the high risks involved in this kind of projects, such as excavation failure or excessive deformation that may result in damage to neighboring buildings, damage to excavation wall and in worst cases some fatality, a comprehensive and especial geotechnical investigation and design is mandatory for sustainable and resilient development of the cities.

Deep excavation in urban areas, and associated possible failures and damages to the project and the neighboring buildings and facilities, is one of the real challenges that has created sever problems in large cities of Iran, endangering the sustainability of the cities. Excavations sometimes go as deep as $70 \mathrm{~m}$ which irrespective of the geotechnical problems, they impose some changes in ground water regime. Indeed, the problems involved in deep excavation projects in urban area, are not merely geotechnical. Some of these types of the problems are listed below:

1. Instabilities and associated damages to the excavation and the buildings in surrounding area; sometimes with fatality;

2. Excessive deformation and damage to the neighboring buildings;

3. Changes in groundwater regime;

4. Disturbance in adjacent traffic;

5. Discomfort for the neighbors;

6. Environmental impacts on the neighboring area and on the city as a whole especially when trees are cut for a project.

All of the above named problems affect the sustainability and resiliency of a city if they are not studied carefully with acceptable solutions for each problem.

The author has been involved in many deep excavation projects mainly in the city of Tehran. All projects have been successfully completed because of the appropriate and comprehensive geotechnical study and design and tight and careful supervision and control of construction. Design and implementation of an appropriate instrumentation for observation of the ground reaction and control of deformation to stay in allowable range is crucial for a successful excavation project. Tuba project in North Tehran is an internationally unique project that has been completed successfully by the author.

The Tuba deep excavation project was conducted in a densely developed area in the North West of Tehran, capital of Iran, to provide space for 7 basement levels for a multipurpose building to be constructed in 3 sides of an existing twin tower of 15 and 21 stories. The maximum excavation depth from the ground surface was $28.5 \mathrm{~m}$ while that from the foundation level of existing buildings was $16.5 \mathrm{~m}$. The necessity for constraining the deformations of the existing towers commended the construction of contiguous concrete piles around the building, supported with tieback and wailing system at 4 different levels. However, the rest of the excavation walls was designed and constructed using nailing method as they were not very sensitive to deformation. Figures 4-6 show the project, in the process of excavation from different views. A monitoring program for measuring the deformations of the tower and supporting system was also enforced during and after excavation to keep everything under control.

Three-dimensional nature of the retaining structure required careful design and construction procedure to avoid problems such as the intersection of the 


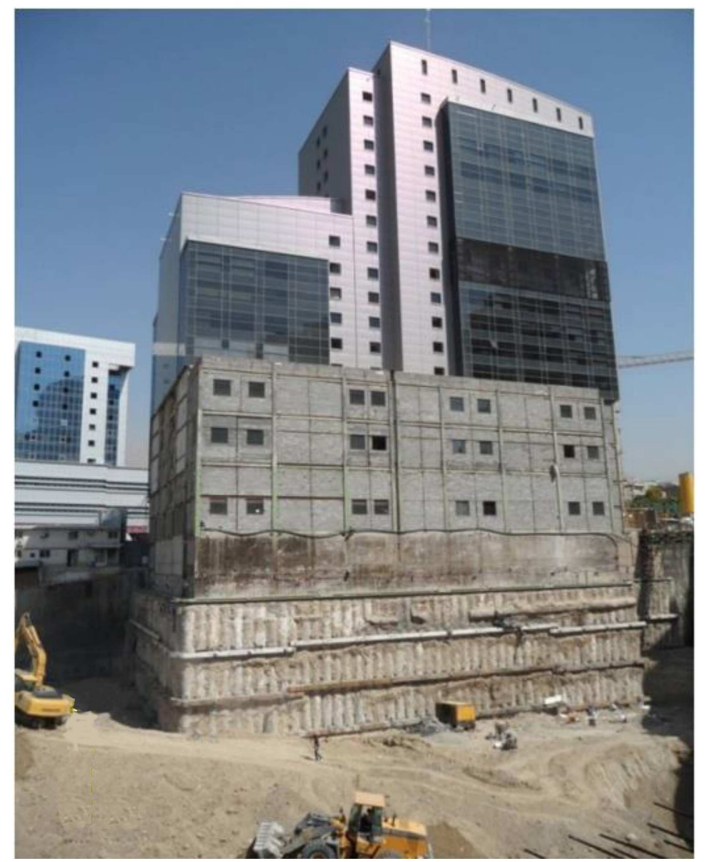

Figure 4. South and west views of the excavation including a view from the existing building.

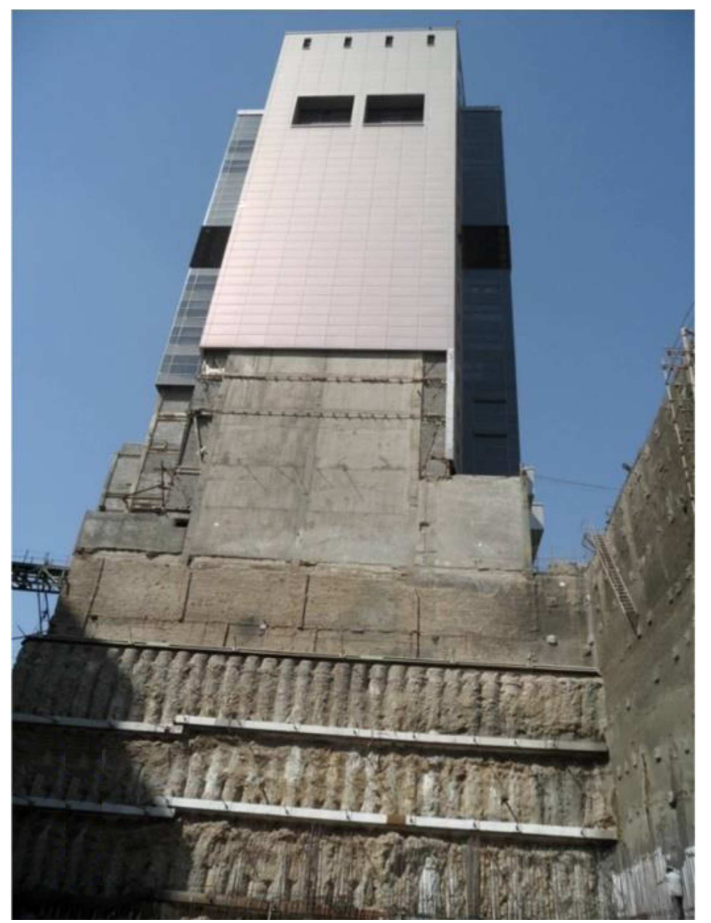

Figure 5. East view of the excavation including a view from the existing building.

anchors in 3 dimensions. Each tieback was given a unique direction which was defined by 3 angles relative to the local $x, y$ and $z$ axes. Therefore, complicated forces were exerted on the wailing system, the piles and the soil. The excavation procedure was planned and executed in a way that ensured no occurrence of excessive deformation in the existing building during

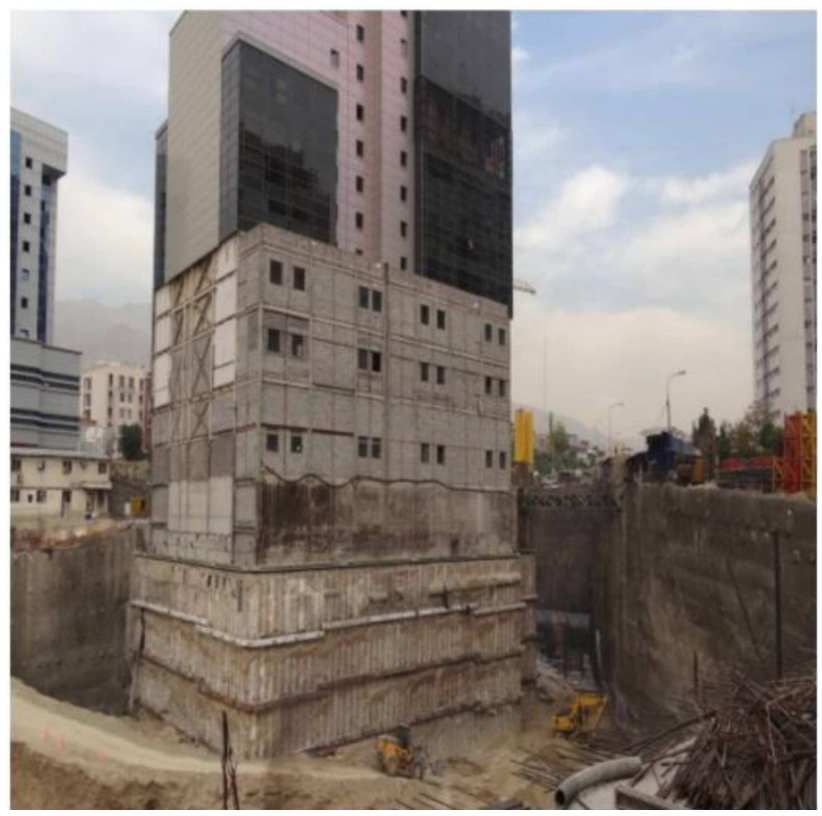

Figure 6. South and west views of the excavation, the retaining system and the existing tower; in this image, all 4 levels of wailing have been installed. Also the nailing system in other parts of the excavation can be observed.

or after the excavation. The retaining structure was designed for earthquake loading as well, to minimize the risk and increase the sustainability and resiliency of the project. For further information on this project the reader is referred to [46-48].

\section{Earthquake geotechnical engineering and its effect on sustainable urban area}

The probability of occurrence of a designated strong earthquake is one of the most important required data when a development is planned in an earthquake prone area. When the probability of occurrence of earthquake is high, then the Geohazards associated with the design earthquake should be taken into consideration and the development should be designed for counteracting that geohazard, in order to grantee sustainability and resiliency of that development with respect to earthquakes. Geohazards of earthquakes can be categorized in two main groups.

a) Ground instabilities due to earthquakes: Landslides, rock falls, liquefaction and associated lateral spreading, subsidence and fault rupture;

b) Local site effects on earthquake characteristics: Amplitude: Amplification of the rock base motion may result in larger earthquake loads on the structures. Period: One of the natural periods of the structure may match with the predominant or an appropriate period of the ground or ground shaking resulting in resonance in the structure. Duration: Elongation of the ground shaking may 
cause problems in terms of additional dynamic loads on the structures.

\subsection{Geotechnical instabilities due to earthquakes}

\subsubsection{Landslides and rockfalls}

Landslides and rockfalls are discussed in Section 3, under the title of slope instability and are not elaborated any more in this section.

\subsubsection{Liquefaction}

Liquefaction is a destructive consequence of earthquakes in saturated loose sandy soils. The shear strength of this type of soil almost vanishes due to the excessive pore water pressure generation during and after an earthquake. Therefore any structure or facility in or on this type of ground experiences heavy damages if precautions and careful geotechnical studies and design are not considered. Many researchers have studied different aspects of this phenomenon in the last 50 years [49-60].

When a city or any development is located in an earthquake prone area and the ground is susceptible to liquefaction, then a comprehensive geotechnical study in this respect should be planned and conducted. Design or remedial measures, either geotechnical or structural, should be implemented for the associated cases to avoid instability, and ensure the sustainability and resiliency for the city. Liquefaction may damage buildings and structures in addition to underground facilities and lifelines. The latter, sometimes, might be more destructive if gas pipelines are involved in the underground lifelines of the city. The fatality and damages due to associated fire as a consequence of breakage in gas pipelines, when they are located in a liquefiable ground, may be more destructive compared to those associated with merely ground shaking. Therefore, prior to any decision on any development, a thorough geotechnical investigation and design aiming on liquefaction study is mandatory and vital; otherwise no sustainable or resilient city can be expected.

\subsubsection{Lateral spreading}

Lateral spreading is a side effect or consequence of liquefaction. It happens when a liquefiable soil is located in a very mild sloping ground or in a level ground ending in an opening like river bank or sea shore. Lateral spreading can dramatically damage buildings, structures, roads, underground facilities and lifelines, coastal or offshore facilities and structures even built on deep foundations or piles. If the problem is geotechnically studied and accordingly, geotechnically and structurally designed, then the damages can be minimized. There are many observations of destructive damages due to liquefaction induced lateral spreading in recent earthquakes such as Loma Prieta (1989), Kobe (1995), and Haiti (2010). Two cases from

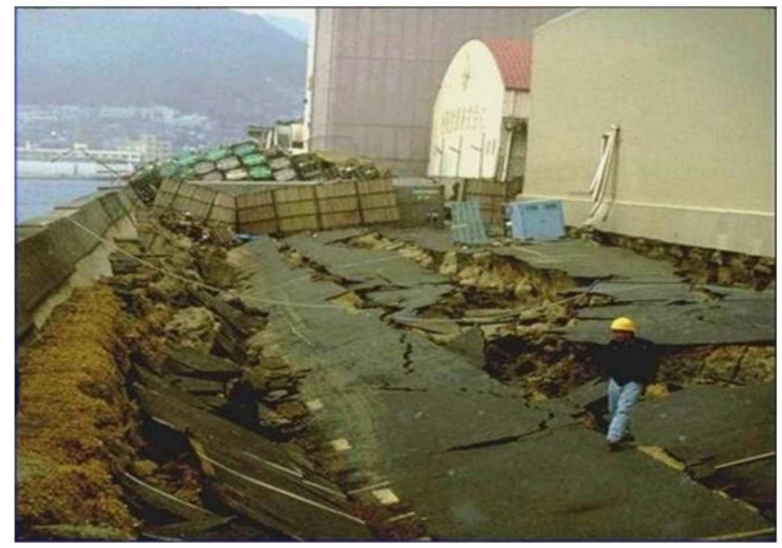

Figure 7. Lateral spreading damage to a quay wall (Kobe earthquake, 1995) [103].

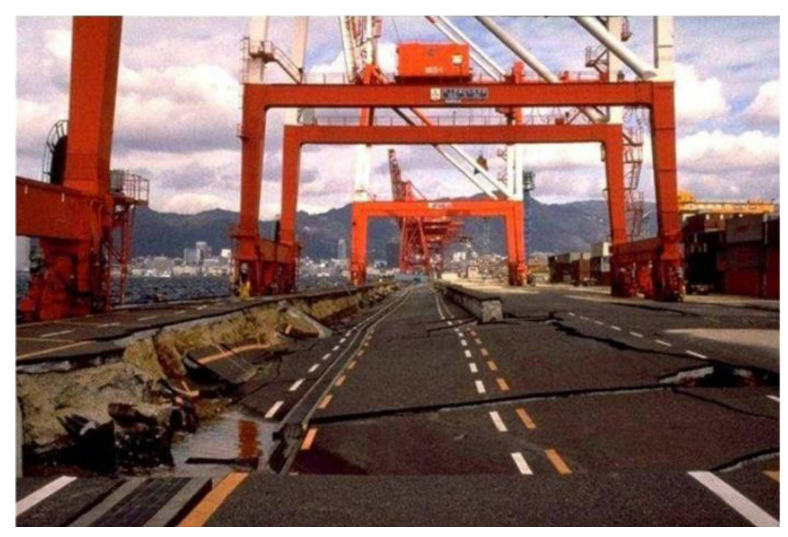

Figure 8. Lateral spreading damage to a quay wall (Kobe earthquake, 1995) [104].

Kobe (1995) earthquake are pictured in Figures 7 and 8 that show the extent of damages associated with lateral spreading. There are numerous theoretical, laboratory and site studies by researchers on the subject of lateral spreading [61-64].

As mentioned before, lateral spreading can damage the piles and deep foundations of structures [6578]. Pile failure under lateral spreading can be due to substantial lateral movement of liquefied soil and associated lateral pressure on the piles, as well as the lateral loads exerted from non-liquefiable crust layer on upper section of the piles. In addition, significant reduction in liquefiable soil stiffness, after triggering of the liquefaction, reduces the lateral resistance of the piles. This mechanism is illustrated in Figure 9.

Based on the recorded cases of damages to the piles due to lateral spreading in Kobe 1995 earthquake, JRA (Japan Road Association) [79] recommended the use of lateral loads shown in Figure 10 as the design lateral loads on piles under lateral spreading.

Evaluation of the effects of lateral spreading on existing structures and development of mitigation measures are among the main steps towards the reduction of hazards associated with such a destructive 


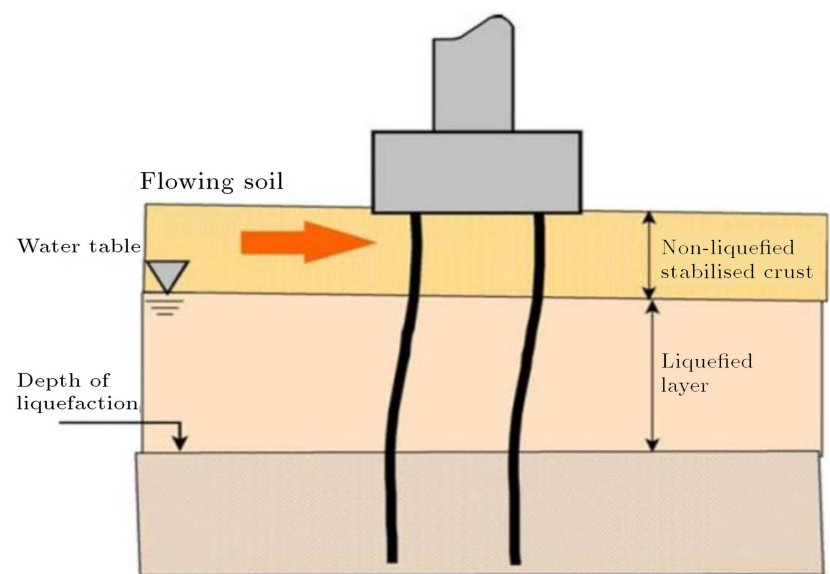

Figure 9. The mechanism and behavior of piles subjected to lateral spreading.

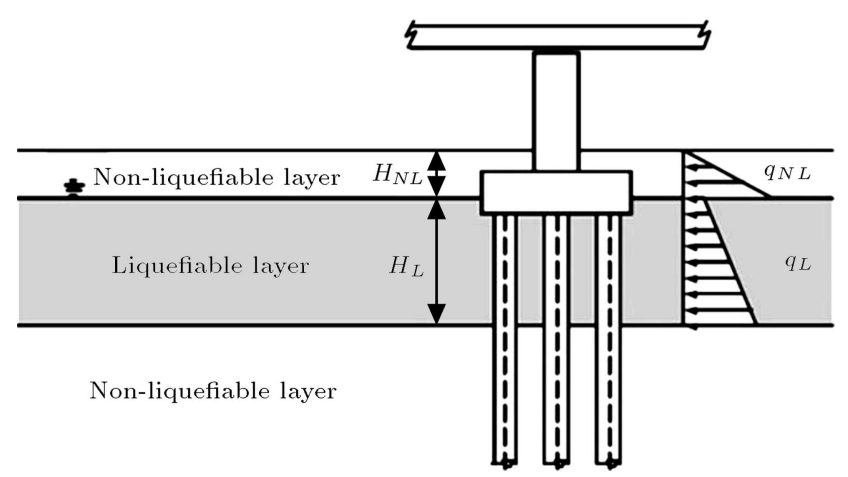

Figure 10. JRA's recommendations for design load on piles under the effect of lateral spreading [79].

phenomenon. In this respect, a comprehensive study for investigating the behavior of deep foundations subjected to lateral spreading has been planned and conducted on Shake Table facilities of Sharif University of Technology using physical modeling [80-87]. For this purpose, a series of large scale physical model experiments consisting of four sets of piles and soil configurations (a group of single piles without pile caps, a $2 \times 2$ pile group, a $3 \times 3$ pile group and a model of a real case all with pile caps), were performed on shake table. During the experiments different parameters of the soil response including soil acceleration and displacement and the variations of excess pore water pressure in the free field as well as in the areas close to the piles were recorded. Also the parameters related to the pile response such as acceleration, displacement and bending moments of the piles were recorded and analyzed. The lateral pressures on the piles due to the lateral spreading were obtained by back calculation of the bending moments of the piles. The results show that the pattern and magnitude of bending moments and lateral pressure on the piles due to lateral spreading are affected by a number of factors including the geometrical and mechanical parameters of the soil layers as well as those of the piles. The affecting soil parameters could be the liquefiable soil density and thickness, presence and characteristics of upper non-liquefiable crust layer, etc. The characteristics of the piles that affect the response include the number of piles, presence of pile cap, location of the pile within the group, number of piles in the group and the rigidity or the flexibility of the piles. The effects of superstructure were also found to be important in this respect. Another finding was that the maximum values of bending moments and soil pressures on different piles of a group were also affected by shadow and neighboring effects. Some of the aforementioned factors are not given full consideration in current codes of practice. In most of the tests, the magnitude of lateral forces on model piles due to lateral spreading was found to be more than that specified by design code of JRA (Japan Road Association) [79]. These facts reveal the necessity of revising current methods of analysis and design of the piles against lateral spreading considering the aforementioned parameters. The settings of the conducted tests are shown in Figures 11-14. The details of the tests and test results are reported in several papers and reports (e.g. [80-87]) and still are underway. In this paper, a summary of some of the selected results are presented to show the need for this kind of research if sustainability and resiliency of the cities, including all facilities and lifelines, are aimed.

Table 1 that is extracted from the data collected from test no. 1 is indicative of how the position of the pile within a group of piles can affect the maximum bending moment associated with lateral spreading on piles. Also, the variations of kinematic soil pressure due to lateral spreading on different piles of test no. 1 at various times are shown in Figure 15. In this figure, the pressure distribution suggested by JRA is also shown for comparison. As shown in this figure, the earth pressure recommended by JRA underestimates the inserted pressure on pile 3 or the single pile. Displacement pattern and some other details of the tested physical models are illustrated in Figures 16-20 that are very instructive.

A summary of the new findings and recommendations based on the test results are given in the following statements:

1. The triangular lateral pressure distribution pattern proposed by JRA is consistent with back-calculated pressures for single piles of the 1st test. However,

Table 1. Bending moment in different piles of test no. 1.

\begin{tabular}{cccccc}
\hline Pile no. & $\mathbf{1}$ & $\mathbf{2}$ & $\mathbf{3}$ & $\mathbf{4}$ & $\mathbf{5}$ \\
\hline $\begin{array}{c}\text { Maximum bending } \\
\text { moment (kN.m) }\end{array}$ & 0.103 & 0.112 & 0.183 & 0.100 & 0.057 \\
\hline
\end{tabular}

Note: Pile 3: single pile; Piles 1 and 2: front and shadow piles; Piles 4 and 5: side and middle piles. 
Displacement transducer

- Accelerometer

- Pore water pressure transducer
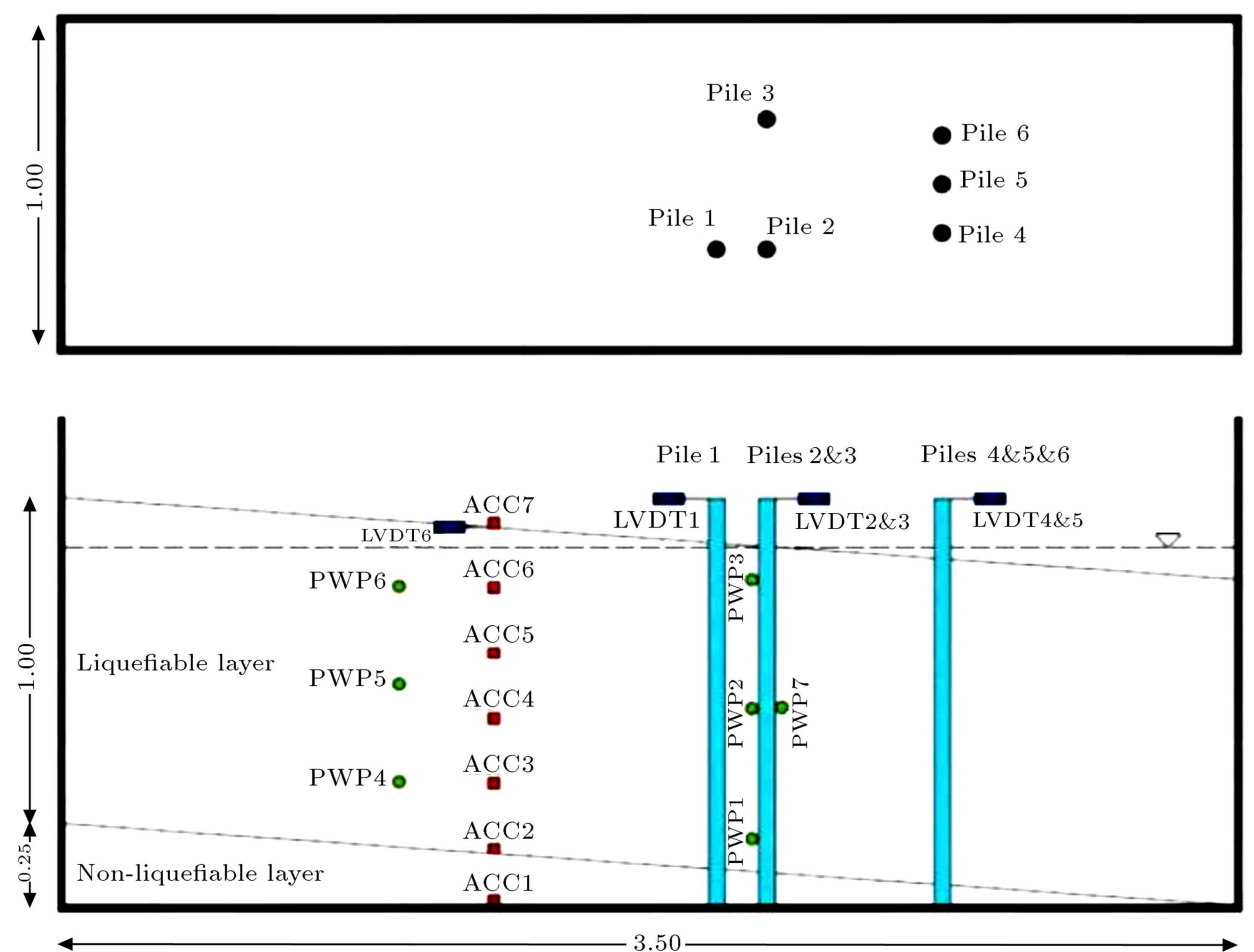

Figure 11. Cross section and plan views of the 1st test on a group of single piles (dimensions in meters).

$\longrightarrow$ Displacement transducer

- Accelerometer

- Pore water pressure transducer
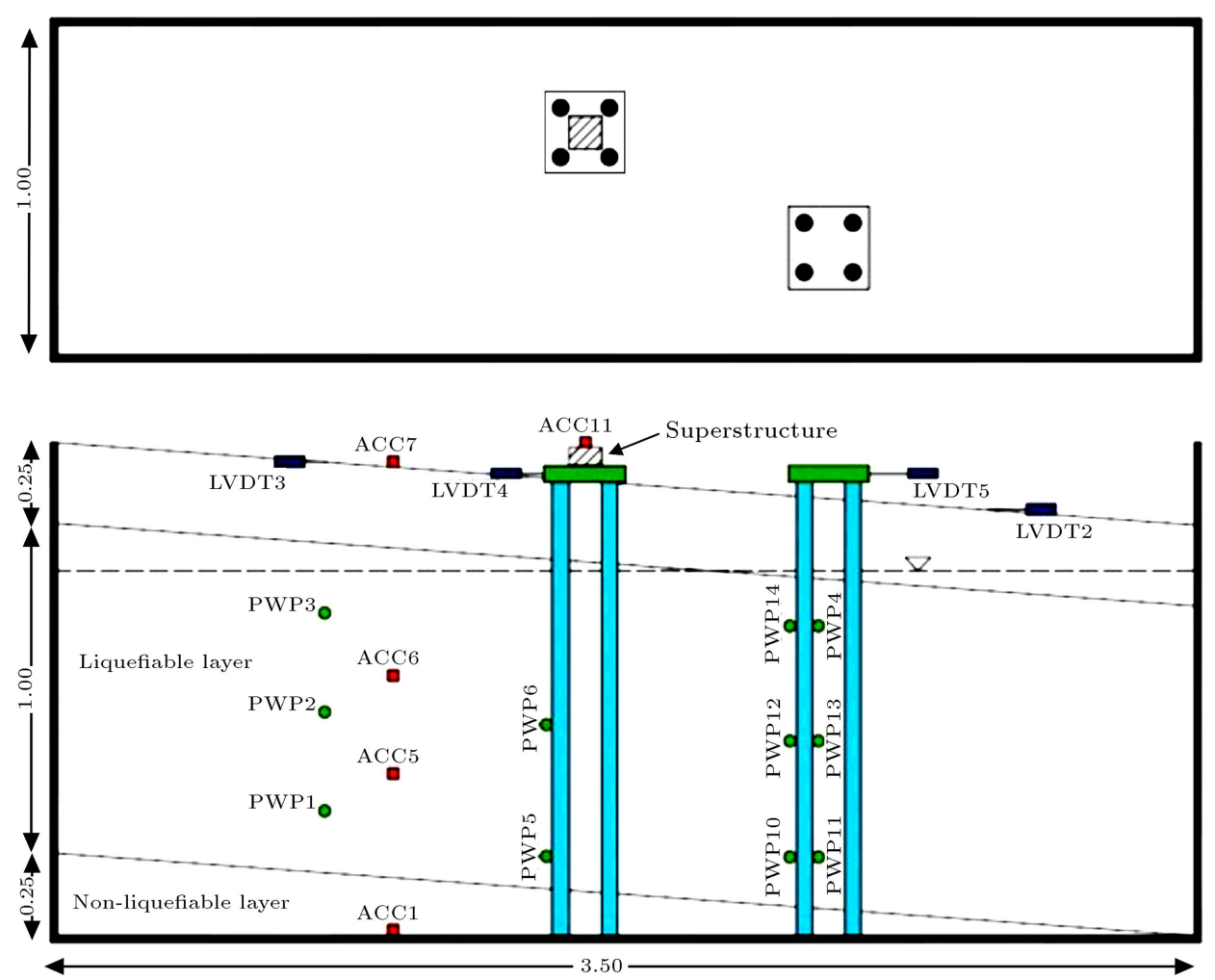

Figure 12. Cross section and plan views of the 2 nd test on $2 \times 2$ pile groups (dimensions in meters). 

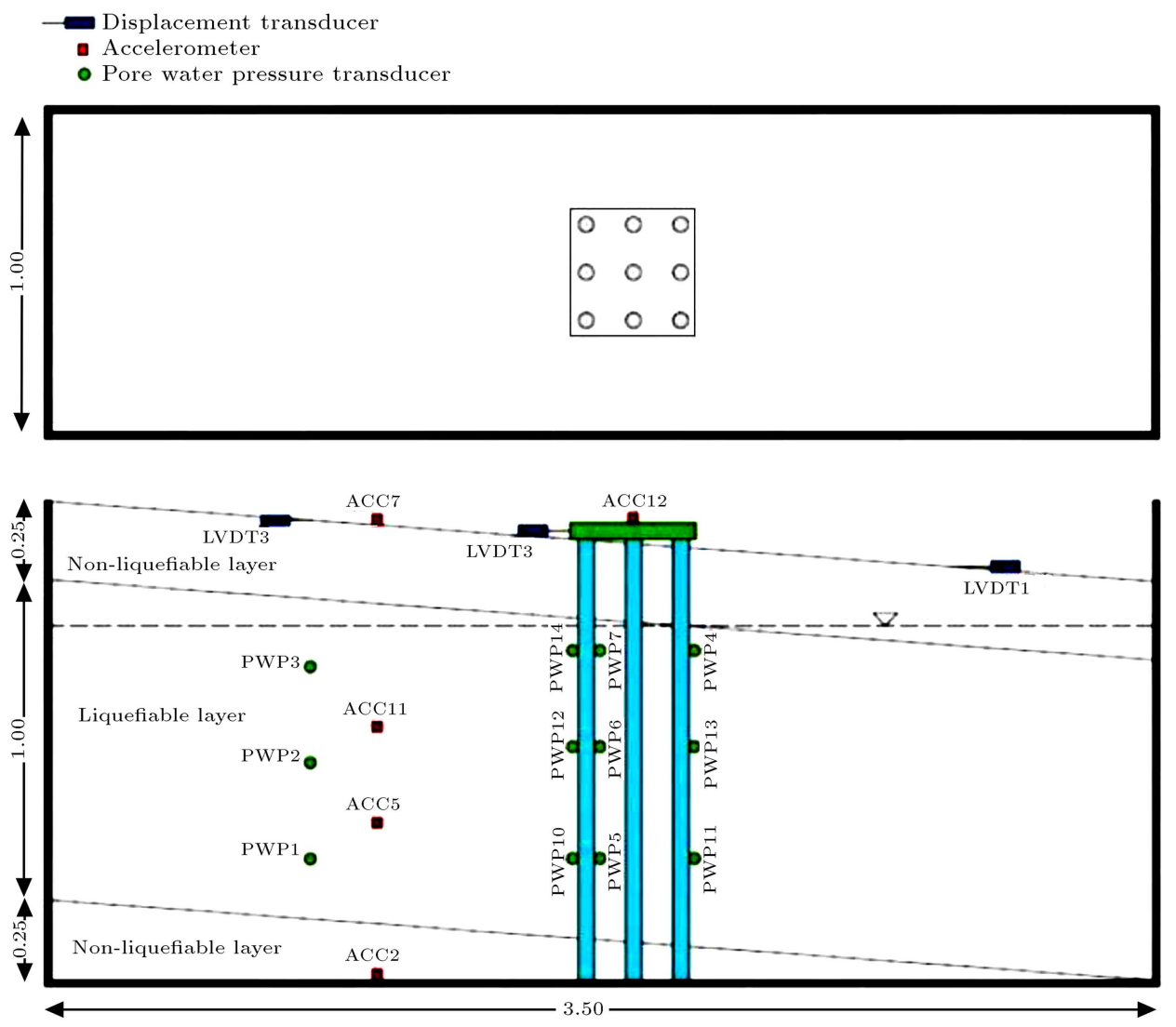

Figure 13. Cross section and plan views of the 3rd test on $3 \mathrm{x} 3$ pile group (dimensions in meters).

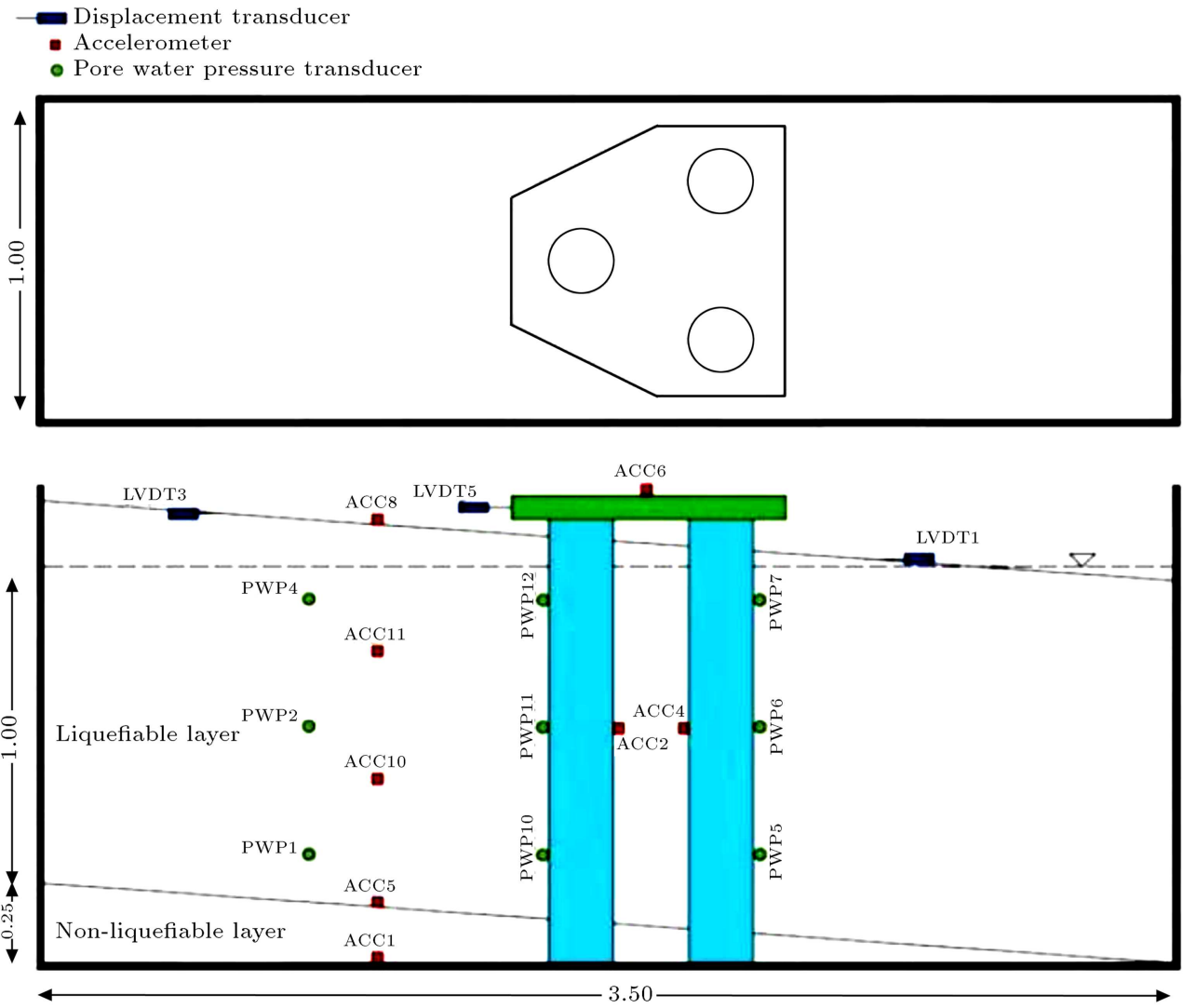

Figure 14. Cross section and plan views of the 4th test: Physical modeling of a marine dolphin (dimensions in meters). 

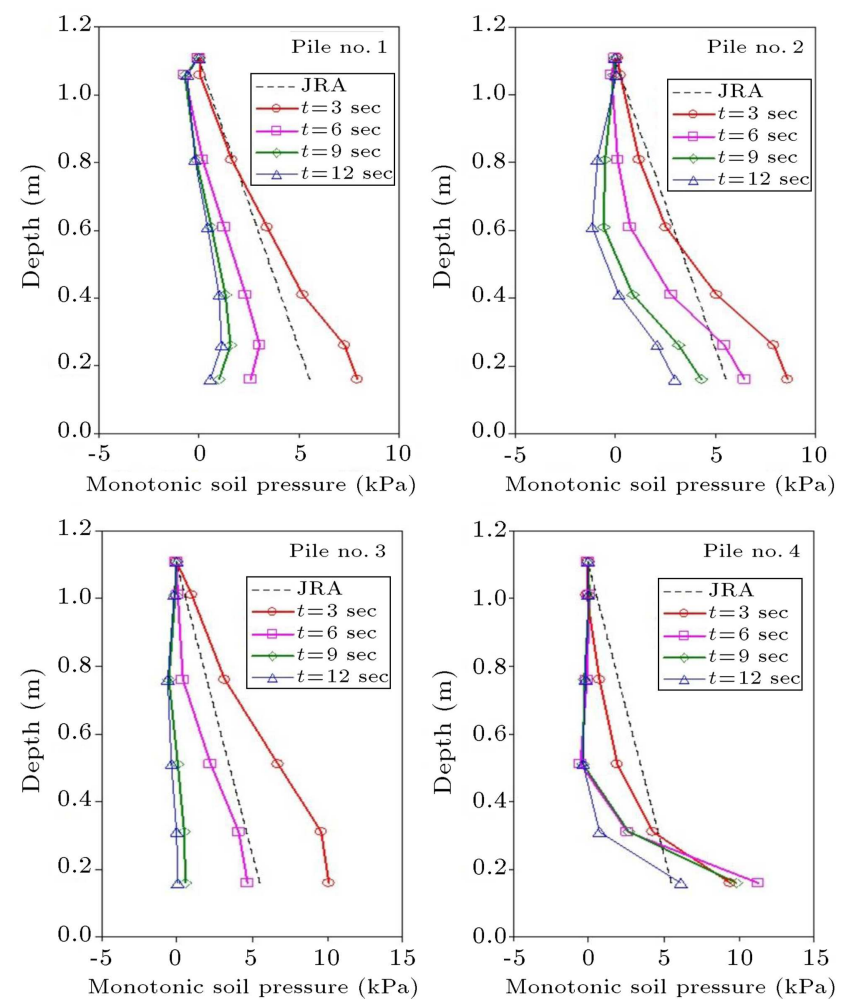

Figure 15. Profiles of lateral pressure induced by lateral spreading on different piles of test no. 1 [83].

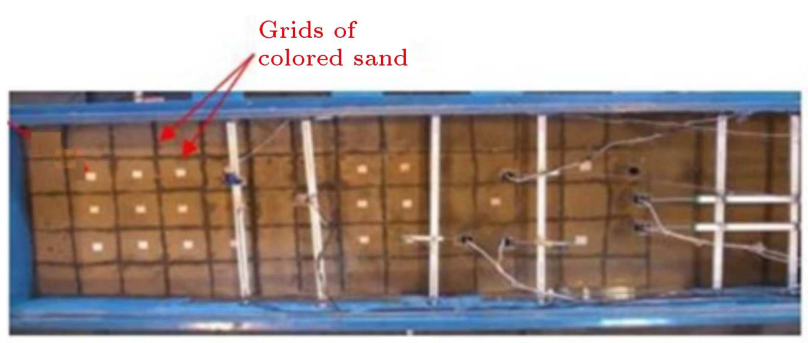

(a)

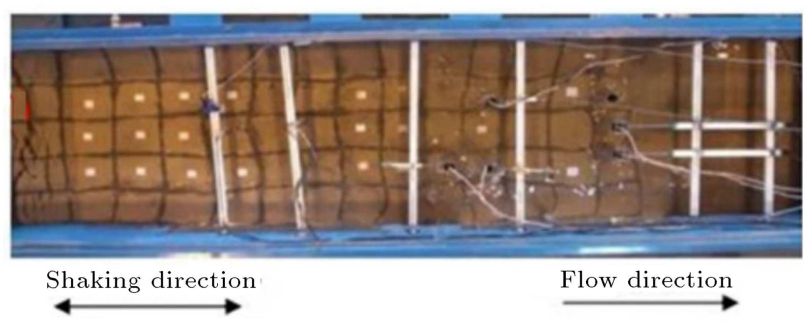

(b)

Figure 16. Displacement pattern at ground surface of test no. 1: a) Before testing; and b) after lateral spreading [83].

JRA underestimates lateral pressure for a single pile up to $85 \%$. Also, in a group of piles (without cap) exerted lateral pressures as well as bending moments in different individual piles of group highly depend on the position of the pile within the group. For example, the downslope or shadow pile in a $2 \mathrm{x} 1$ pile group arranged parallel to lateral spreading

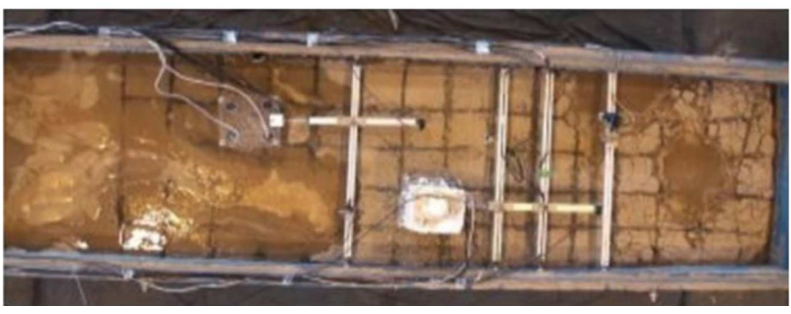

Figure 17. Ground surface after liquefaction and lateral spreading in test no. 2. Note the development of tension cracks at upslope and development of sand boils at different places [85].

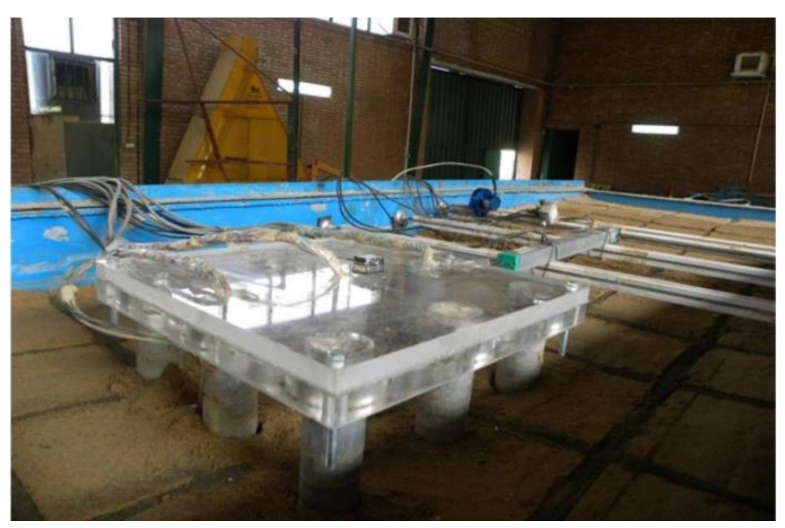

Figure 18. A general view of the $3 \times 3$ pile group in the 3rd test.

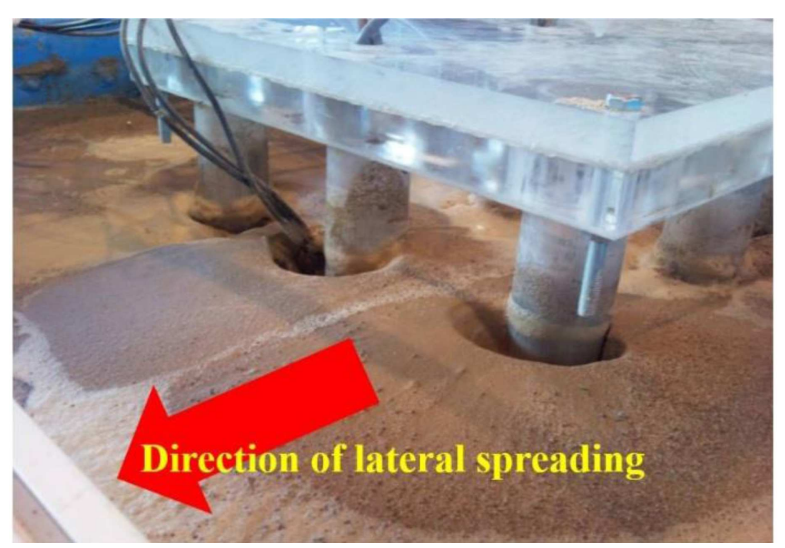

Figure 19. Gap formation at the downslope side of the piles in the downslope row of $3 \times 3$ pile group and heave of soil at the upstream side of the piles in test no. 3 [83].

direction, receives less pressure than the upslope or front pile. Also, individual piles of a $1 \times 3$ receive considerably less pressures than a single pile and the middle pile of a $1 \times 3$ receive about $35 \%$ of the pressures exerted on the side piles. As a result current practice based on substituting a pile group with a single pile for lateral spreading analysis does not seem to be reliable;

2. Total lateral load on a $2 \times 2$ pile group is about $70 \%$ higher than the value recommended by JRA code and total lateral load on a $3 \times 3$ pile group is about 


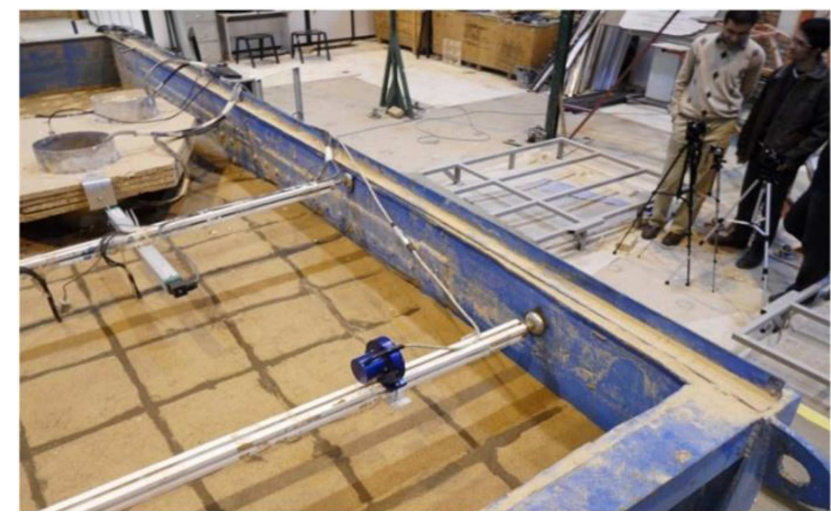

Figure 20. Lateral spreading and associated settlement at upslope side of the ground in test no. 4 [87].

$10 \%$ higher than the value recommended by JRA code which is almost negligible;

3. According to JRA, individual piles within a group take similar share of the total lateral pressure designated by JRA. However the experiment on pile groups indicates that the exerted lateral pressures as well as bending moments in individual piles of the group highly depend on the position of the pile within the group.

For earthquake resistant design of structures in the sites located in earthquake prone area, according to JRA and also new Iranian code for earthquake resistant design of building (Standard 2800) [88], if a structure is built on deep foundation in a ground susceptible to lateral spreading, three steps should be taken for the assessment of the response of the building to the design earthquake:

1. Design building with the assumption of no liquefaction and associated lateral spreading. Consider the earthquake loading based only on the wave propagation and ground acceleration amplification;

2. Design building with the assumption of liquefaction occurrence with no liquefaction induced lateral spreading;

3. Design building with the assumption of lateral spreading. In this case, the inertial force due to earthquake should not be added to the lateral force induced by lateral spreading on deep foundation, as the lateral spreading induces kinematic forces that usually happen after the earthquake.

As a concluding remark one would comment that if a site, a part of a city, or the total area of a city, is susceptible to liquefaction or lateral spreading, only appropriate geotechnical investigation and design with respect to liquefaction and lateral spreading can bring a sustainable and resilient condition for that city in this respect.

\subsubsection{Fault displacement}

If a development is located on an active fault zone, the engineer should consider the possible fault displacement in his design and construction with an expectation of some damages. Another solution is to abandon the place and find a safer site well away from the fault zone. Some destructive recent cases of fault displacement in urban area during earthquakes are Christchurch $(2010,2011)$ in New Zealand, Chi Chi (1999) in Taiwan, and Kocaeli (1999) in Turkey [89-99].

The foundation system plays a key role in the response of structures subjected to faulting induced ground deformation. Depending on the relative stiffness of the foundation, the superstructure will either rotate as a rigid-body without being substantially distressed, or will follow the faulting-induced deformation profile of the ground surface [100-101].

The main aspect on this subject, to the author's opinion, is the relative stiffness of the ground and the foundation system of the building. If the foundation and the building are rigid compared to the ground, then the fault may change its direction near the ground surface, or the structure rotates rigidly which can still be functional, as shown in Figures 21-23.

Structures lying on continuous and rigid mat or box-type foundations perform much better than the ones on discontinuous isolated footings or piles. Even if the diversion is partial, the rigidity of such foundations "spreads" the deformation and allows the structure to

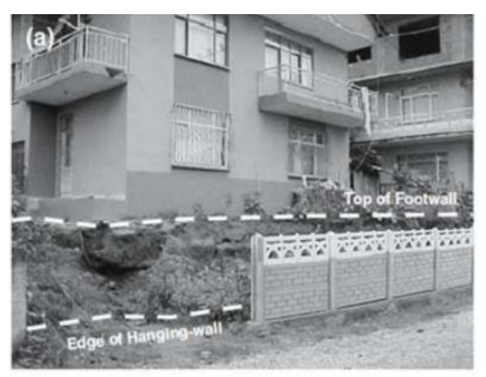

(a)

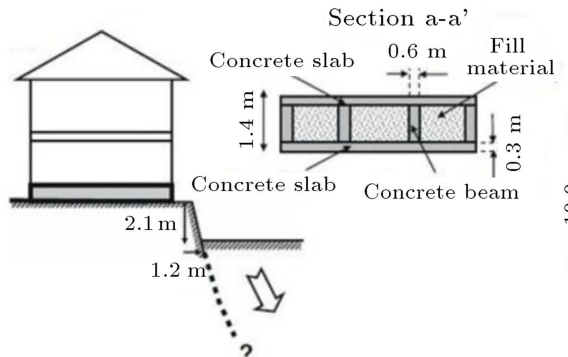

(c)

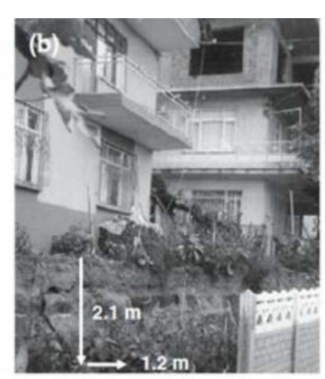

(b)

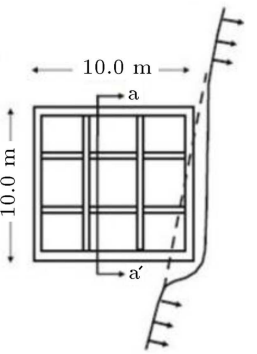

(d)
Figure 21. Change in the fault direction near the ground surface resulted in preservation of a building on a relatively rigid foundation in Kocaeli 1999 earthquake. The reinforced concrete building comprises 2 stories and an attic; its box-type foundation system is quite rigid, comprising stiff concrete beams "sandwiched" between a mat and a top slab [101]. 

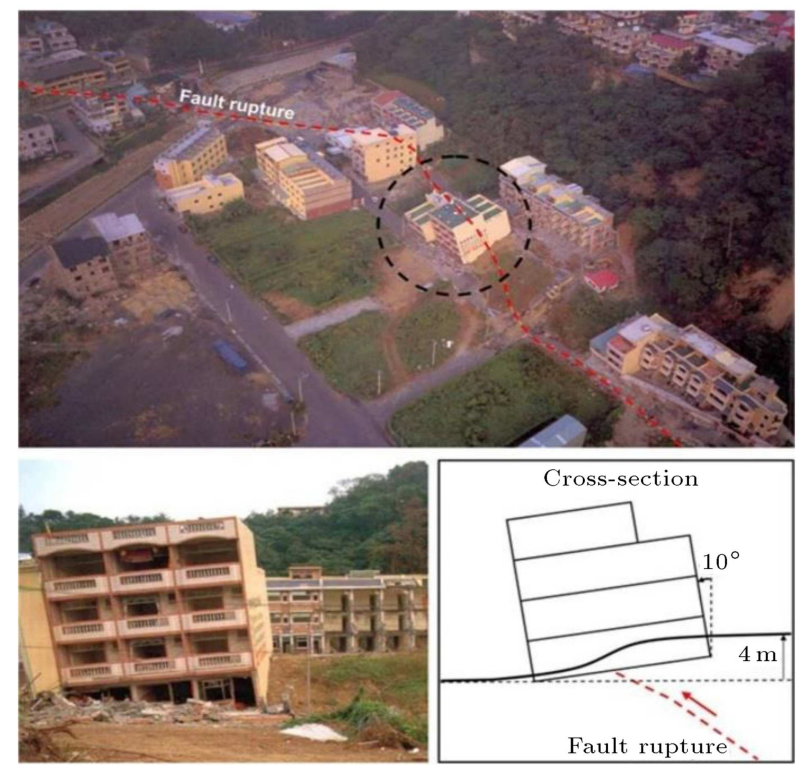

Figure 22. The behavior of a rigid structure to a thrust fault movement, Chi Chi 1999 earthquake: 4-story building resting on a continuous and rigid foundation; the building survived $4 \mathrm{~m}$ of upthrust without substantial structural damage, but subjected to approximately $10^{\circ}$ of rigid-body rotation [100].

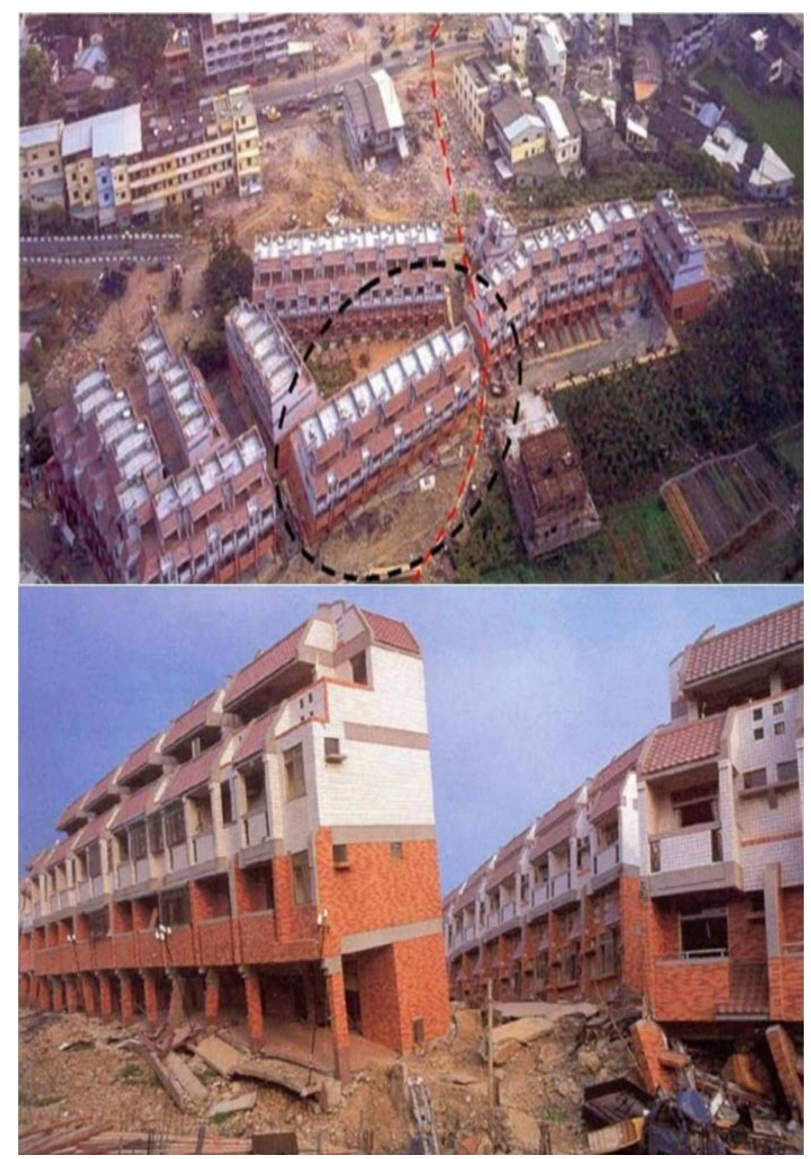

Figure 23. Damage to the 4-story building resting on a relatively flexible foundation located on an active fault in Chi Chi 1999 earthquake [100]. rotate as a rigid body, without experiencing significant distortion and distress [101-102].

\subsubsection{Subsidence}

If the development is over any cavity in the ground like Qanats, underground metro station, mines or karstic caves, the damage to the roof and/or collapse of the opening results in heavy damage to the structures built on that ground. Also, if the ground type is of the nature of loose, unconsolidated dry sand, any earth shaking may result in subsidence in that deposit which may heavily damage the developments. In both cases, an appropriate geotechnical investigation and design can warranty the sustainability and resiliency for that development or city.

Subsidence associated with ground water pumping and extraction is another problem which affects many cities in Iran and in the world. Damages associated with this kind of subsidence can be minimized with a thorough geotechnical investigation.

\section{Underground structures and tunnels}

Roads and City Highway Tunnels are becoming common in the recent decades especially in Tehran to minimize the traffic Jam. Metro tunnels and underground excavations for the metro stations are very important elements for a sustainable and resilient city. Underground structures and cavities like metro stations may collapse and cause ground subsidence like: Kobe Metro station in 1995.

Underground power plants are usually in dam sites and karst cavities and caves are usually in rural areas whereas Qanats are present in Iranian cities, however, geological and geotechnical investigation can help to avoid associated problems.

\section{Geo-environmental aspects}

Buried disposal and its effects on ground water (dilution) and also its environmental impact in addition to its stability problems need associated geotechnical engineering investigations and design for a sustainable and resilient city.

\section{Conclusion}

In this paper the importance and necessity of geotechnical investigations and design for having a sustainable development or city are clarified. In addition, different aspects of geohazards that endanger the sustainability and resiliency of the urban area are briefly discussed and some important aspects of geohazards and some counteracting measures for minimizing their destructive effects are elaborated in some details. On this basis, the main and most important conclusion of this 
paper can be summarized in a sentence that without appropriate geotechnical investigation and design, no sustainability and resiliency can be achieved for any development or any city.

\section{References}

1. Horng, V., Tanaka, H. and Obara, T. "Effects of sampling tube geometry on soft clayey sample quality evaluated by nondestructive methods", Soils and Foundations, 50(1), pp. 93-107 (2010).

2. Pelletier, J.H., Olson, R.E. and Rixner, J.J. "Estimation of consolidation properties of clays from field observations", Geotech. Testing J., 2(1), pp. 34-43 (1979).

3. Ladd, C.C., Whittle, A. and Legaspi Jr. D.E. "Stressdeformation behavior of an embankment on Boston blue clay", Vertical and Horizontal Deformations of Foundations and Embankments. ASCE, Reston, Va., pp. 1730-1759 (1994).

4. Solberg, I.L., Hansen, L., Ronning, J.S., Haugen, E.D., Dalsegg, E. and Tonnesen, J.F. "Combined geophysical and geotechnical approach to ground investigations and hazard zonation of a quick clay area mid Norway", Bulletin of Engineering Geology and the Environment, 71, pp. 119-133 (2012).

5. Osenquist, I.T. "Considerations on the sensitivity of Norwegian quick-clays", Geotechnique, 3, pp. 195-200 (1953).

6. Gregersen, O., The Quick Clay Landslide in Rissa, Norway. The Sliding Process and Discussion of Failure Modes Norwegian Geotechnical Institute, Publication No. 135 (1981).

7. Khaldoun, A., Moller, P., Fall, A., Wegdam, G., De Leeuw, B., Me'heust, Y., Fossum, J.O. and Bonn, D. "Quick clay and landslides of clayey soils", Physical Review Letters, 103(4), 188301 (2009).

8. Alonso, E.E., Lloret, A., Gens, A. and Yang, D.Q. "Experimental behavior of highly expansive doublestructure clay", Proc., 1st. Int., Conf., Unsaturated Soils, Paris, 1, pp. 11-16 (1995).

9. Alonso, E.E., Gens, A. and Josa, A. "A constitutive model for partially saturated soils", Géotechnique, 40(3), pp. 405-430 (1990).

10. Alwail, T.L., Ho, C.L. and Fragaszy, R.J. "Collapse. mechanism of compacted clayey and silty sands collapse of compacted clayey sands", 279 ASCE, Conf., Vertical and Horizontal Deformation of Foundations and Embankments, 2, College Station, TX, USA, pp. 1435-1446 (1994).

11. Bao, C., Bewei, G. and Liangtong, Z. "Properties of unsaturated soils and slope stability of expansive soils", Keynote Lecture, UNSAT 98., 2nd International Conference on Unsaturated Soils, Academy of Railway Science, Beijing, China, pp. 27-30 (1998).

12. Dakshanamurthy, V. "A stress-controlled study of swelling characteristics of compacted expansive clays", ASTM, Geotechnical Testing Journal, 2(1), pp. 57-60 (1979).

13. Foster, M., Fell, R. and Spannagle, M. "A method for assessing the relative likelihood of failure of embankment dams by piping", Canadian Geotechnical Journal, 37, pp. 1025-1061 (2000).

14. Soroush, A., Miri Disfani, M. and Tabatabaie Shourijeh, P. "Potential of internal instability in alluvial sediments", 59th Canadian Geotechnical Conference, 8-10 October 2006, Vancouver, Canada, pp. 11561163 (2006).

15. Soroush, A., Tabatabaie Shourijeh, P. and Miri Disfani, M. "A laboratory study on some factors effecting suffusion in soils", Proceedings of the 13th Asian Regional Conference on Soil Mechanics and Geotechnical Engineering, 10-14 December 2007, Kolkata, India (2007).

16. Fannin, R.J. and Moffat, R. "Observations on internal stability of cohesionless soils", Géotechnique, 56(7), pp. 497-500 (2006).

17. Wan, C.F. and Fell, R. "Assessing the potential of internal instability and suffusion in embankment dams and their foundations", Journal of Geotechnical and Geoenvironmental Engineering, ASCE, 134(3), pp. 401-407 (2008).

18. Cividini, A., Bonomi, S., Vignati, G.C. and Gioda, G. "Seepage-induced erosion in granular soil and consequent settlements", International Journal of Geomechanics, ASCE, 9(4), pp. 187-194 (2009).

19. Burenkova, V.V. "Assessment of suffosion in noncohesive and graded soils", Proceedings, the First International Conference "Geo-Filters", Karlsruhe, Germany, 20-22 October 1992, Filters in Geotechnical and Hydraulic Engineering, Brauns, Heibaum \& Schuler, Eds., Balkema, Rotterdam, pp. 357-360 (1993).

20. Kenney, T.C. and Lau, D. "Internal stability of granular filters", Canadian Geotechnical Journal, 22, pp. 215-225 (1985).

21. Fannin, R.J. and Moffat, R. "Observations on internal stability of cohesionless soils", Geotechnique, 56(7), pp. 497-500 (2006).

22. Alawaji, H.A. "Shear induced collapse settlement of arid soils", Geotechnical and Geological Engineering, 19(1), pp. 1-19. 7 (2001).

23. Alkandari, F.A. "Collapse of cemented carbonate sand", PhD Thesis, Department of Civil, Environmental and architectural Engineering, University of Colorado, USA (2000).

24. Alonso, E.E., Gens, A. and Hight, D.W. "Special problems in soils", General report, Proc. 9th Eur, Conf, Soil Mech., Dublin, pp. 1087-1146 (1987).

25. Booth, A.R. "Collapse settlement in compacted soils", CSIR Research Report 324, National Institute for Transport and Road Research, Bulletin No. 13, pp. 1-40 (1977). 
26. Chiu, C.F., Ng, C. and Shen, C.K. "Collapse behavior of loosely compacted virgin and non-virgin fills in Hong Kong", Proc. 2nd Int. Conf. Unsaturated Soils, 1, Beijing, China, pp. 25-30 (1998).

27. Clevenger, W.A. "Experience with loess as foundation material", ASCE, J. Soil Mech. \& Fdns. Div., 85, pp. 151-180 (1958).

28. Dudley, J.H. "Review of collapsing soils", $A S C E$, Journal of Soil Mechanics and Foundation Engineering, 96, SM3, pp. 925-947 (1970).

29. Elkady, T.Y. "Static and dynamic behavior of collapsible soils", PhD Thesis, Arizona State University, USA (2002).

30. Elkady, T.Y., Houston, S.L. and Houston, W.N. "Static and dynamic behavior of hydro-collapse soils", ASTM, Geotechnical Testing Journal, 34(5), pp. 537-550 (2011).

31. Handy, R.L. "Collapsible loess in Iowa", Proceedings of the Soil Science Society of America, 37(2), pp. 281284 (1973).

32. Jennings, J.E.B. and Knight, K. "A guide to construction on or with materials exhibiting additional settlement due to "collapse" of grain structure", Proceedings Sixth Regional Conference for Africa on Soil Mechanics and Foundation Engineering, pp. 99105, Durban (1975).

33. Haeri, S.M., Zamani, A. and Garakani, A.A. "Collapse potential and permeability of undisturbed and remolded loessial soil samples", Springer, Unsaturated Soils: Research and Applications, pp. 301-308 (2012a).

34. Haeri, S.M. and Garakani, A.A. "The variation of total volume change, water volume change, yielding net confining stress and shear strength of undisturbed unsaturated loess under isotropic compression", Springer, Unsaturated Soils: Research and Applications, pp. 293-300 (2012b).

35. Haeri, S.M., Garakani, A.A. and Khorshidi, M. "Collapse potential and variation of the water content in undisturbed loessial samples under $\mathrm{k} 0$ condition and controlled matric suction", 9th International Congress on Civil Engineering, Tehran, Iran (2012c).

36. Haeri, S.M., Khorshidi, M. and Akbari Garakani A. "Variation of the volume change and water content of undisturbed loessial samples in controlled matric suction odometer tests", 4th International Conference on Problematic Soils, Wuhan, China (2012d).

37. Haeri, S.M., Garakani, A.A., Khosravi, A. and Meehan, C.L. "Assessing the hydro-mechanical behavior of collapsible soils using a modified triaxial test device", Geotechnical Testing Journal ASTM, 37(2), pp. 190-204, DOI: 10.1520/GTJ20130095 (2014a).

38. Haeri, S.M., Ghazizadeh, S., Zabihi, N. and Garakani, A.A. "Evaluation and comparison of water retention curves for undisturbed, reconstituted and improved loessial soils", 1st National Geoechnical Engineering Conference, Ardebil, Iran (2013a).
39. Haeri, S.M., Khosravi, A., Ghazizadeh, S., Garakani, A.A. and Meehan, C.L. "Characterization of the effect of disturbance on the hydro-mechanical behavior of a highly collapsible loessial soil", Unsat2014, Sydney, Australia (2014b).

40. Haeri, S.M., Khosravi, A. and Ghazizadeh, S. "The measurement of suction stress characteristic curve for a highly collapsible loessial soil", IFCEE2015, San Antonio, Texas, USA (2015).

41. Haeri, S.M., Garakani, A.A. and Ruhparvar, H.R. "Evaluation of improvement of the base of an irrigation canal in a loessial soil by lime using oedometer tests and numerical modeling", 3rd National Seminar on Irrigation Channels, Karaj, Iran (2012e).

42. Haeri, S.M., Garakani, A.A. and Ruhparvar, H.R. "Effect of lime improvement on collapsibility of gorgan loess using double oedometer and unsaturated oedometer tests", 2nd Conference on Geotechnics, Earthquakes and Structures, Iran (2012f).

43. Ruhparvar, H.R. "Evaluation of lime improvement of collapsible soils using double oedometer and unsaturated oedometer tests", MSc Dissertation, Civil Engineering Department, Sharif University of Technology (2012).

44. Zabihi, N. "Evaluation of lime improvement of loessial soil of Gorgan using unsaturated oedometr tests", MSc Dissertation, Civil Engineering Department, Sharif University of Technology (2013).

45. Garakani, A.A. "Laboratory assessment of the hydromechanical behavior of unsaturated undisturbed collapsible soils - case study: Gorgan loess", Dissertation submitted for partial fulfillment of $\mathrm{PhD}$ degree, Department of Civil Engineering, Sharif University of Technology, Tehran, Iran (2013).

46. Haeri, S.M., Sasar, M. and Afshari, K. "Deep excavation on 3 sides of a 21 story building: accounts of a successful deep excavation project", 7th International Conference on Case Histories in Geotechnical Engineering, Chicago (2013).

47. Haeri, S.M., Shakeri, M.R. and Sasar, M., Tuba Project Design Report, Towse-e-Paydar Engineering Management Company, Tehran, Iran (2010).

48. Haeri, S.M. and Shakeri, M.R., Tuba Project Design Criteria, Towse-e-Paydar Engineering Management Company, Tehran, Iran (2010).

49. Al Khatib, M. "Liquefaction assessment by strain energy approach", PhD Dissertation, Wayne State University (1994).

50. Idriss, R.M. and Boulanger, R. . "Soil liquefaction during earthquakes", Report No. MNO-12, Earthquake Engineering Research Institute, California (2008).

51. Ishibashi, I., Sherif, M.A. and Tsuchiya, C. "Porepressure rises mechanism and soil liquefaction", Soils and Foundations, 17(2), pp. 7-27 (1977).

52. Maher, M.H. and Gucunski, N., Liquefaction and Dynamic Properties of Grouted Sand, ASCE Geotechnical special publication, 49, pp. 37-50 (1996). 
53. Ostadan, F., Deng, N. and Arango, I. "Energybased method for liquefaction potential evaluation, phasei - feasibility study", U.S. Department of Commerce, Technology Administration, National Institute of Standards and Technology, Building and Fire Research Laboratory (1996).

54. Poulos, S.J., Castro, G. and France, J.W. "Liquefaction evaluation procedure", ASCE Journal of Geotechnical Engineering, 111(6), pp. 772-792 (1985).

55. Seed, H.B. and Peacock, W.H. "Test procedures for measuring soil liquefaction characteristics", $A S C E$ Journal of the Soil Mechanics and Foundations, 97, pp. 1099-1119 (1971).

56. Seed, H.B., Martin, P.P. and Lysmer, J. "The generation and dissipation of pore water pressure during soil liquefaction", Report No. EERC 75-26, Earthquake Engineering Research Centre, University of California, Berkeley, USA (1975).

57. Bardet J.P., Cetin K.O., Lettis W., Rathje, E., Rau, G., Seed, R.B. and Ural, D. "Chapter 7: Soil liquefaction, landslides and subsidences. Earthquake Spectra", EERI, 16, pp. 141-162, December (2000).

58. Cetin, K.O., Bilge, H.T., Wu, J., Kammerer, A. and Seed, R.B. "A probabilistic model for the assessment of cyclically-induced reconsolidation (volumetric) settlements", ASCE J. of Geotech. and Geoenvir. Eng., 135(3), pp. 387-398 (2009).

59. Ghalandarzadeh, A., Towhata, I., Orita, T. and Yun, F. "Shaking table tests on seismic behavior of quay walls subjected to backfill liquefaction", In Geotechnical Earthquake Engineering and Soil Dynamics III, pp. 1045-1056, ASCE (1998).

60. Ishihara, K., Haeri, S.M., Moinfar, A.A., Towhata, I. and Tsnjino, S. "Geotechnicalaspects of the june 20, 1990, Manjil Earthquake, in Iran", Soils \& Foundations, Jr. of Japanese Geotechnical Society, 32(3), pp. 61-78 (1992).

61. Bartlett, S.F. and Youd, T.L. "Empirical prediction of liquefaction-induced lateral spread", Journal of Geotechnical Engineering, ASCE, 121(4), pp. 316329 (1995).

62. Fiegel, G.L. and Kutter, B.L. "Liquefaction induced lateral spreading of mildly sloping ground", Journal of Geotechnical Engineering, ASCE, 120(12), Dec (1994).

63. Iai, S. "Similitude for shaking table tests on soilstructure-fluid model in $1 \mathrm{~g}$ gravitational field", Soils and Foundations, JSSMFE, 29(1), pp. 105-118 (1989).

64. Rauch Alan, F. "EPOLLS: An empirical method for predicting surface displacements due to liquefaction -induced lateral spreading in earthquakes", $\mathrm{PhD}$ Thesis, Department of Civil Engineering, Virginia Polytechnic Institute (1997).

65. Abdoun, T. and Dobry, R. "Evaluation of pile foundation response to lateral spreading", Soil Dynamics and Earthquake Engineering, 22(9-12), pp. 1051-1058 (2002).
66. Abdoun, T., Dobry, R., O'Rourke, T.D. and Goh, S.H. "Pile response to lateral spreads: centrifuge modeling", Journal of Geotechnical and Geoenvironmental Engineering, 129(10), Oct., pp. 869-878 (2003).

67. Brandenberg, S.J., Boulanger, R.W., Kutter, B.L. and Chang, D. "Behavior of pile foundations in laterally spreading ground during centrifuge tests", J. Geotech. Geoenviron. Eng., 131(11), pp. 1378-1391 (2005).

68. Brandenberg, S.J., Boulanger, R.W., Kutter, B.L. and Chang, D. "Static pushover analyses of pile groups in liquefied and laterally spreading ground in centrifuge tests", J. Geotech. Geoenviron. Eng., 133(9), pp. 1055-1066 (2007).

69. Cubrinovski, M., Kokusho, T. and Ishihara, K. "Interpretation from large scale shake table tests on piles undergoing lateral spreading in liquefied soils", Soil Dynamics and Earthquake Engineering, 26 pp. 275286 (2006).

70. Cubrinovski, M., Uzuoka, R., Sugita, H., Tokimatsu, K., Sato, M., Ishihara, K., Tsukamoto, Y. and Kamata, T. "Prediction of pile response to lateral spreading by $3-\mathrm{D}$ soil-water coupled dynamic analysis: Shaking in the direction of ground flow", Soil Dynamics and Earthquake Engineering, 28, pp. 421435 (2008).

71. Dobry, R., Abdoun, T., O'Rourke, T.D. and Goh, S.H. "Single piles in lateral spreads: field bending moment evaluation", Journal of Geotechnical and Geoenvironmental Engineering, 129(10), Oct., pp. 879-889 (2003).

72. Gonzalez, L. "Centrifuge modeling of pile foundation response to liquefaction and lateral spreading: Study of sand permeability and compressibility effects using scaled sand technique", PhD Thesis, Rensselaer Polytechnic Institute, Troy, New York (2008).

73. He, L. "Liquefaction-induced lateral spreading and its effects on pile foundations", $\mathrm{PhD}$ dissertation, Univ. of California, Dept. of Structural Engineering, San Diego (2005).

74. Tokimatsu, K. "Performance of pile foundations in laterally spreading soils", In: Seco e PintoP, Editor. Proceedings of the Second International Conference on Earthquake Geotechnical Engineering, 3, pp. 95764 (1999).

75. Motamed, R. and Towhata, I. "Shaking table model tests on pile groups behind quay walls subjected to lateral spreading", Journal of Geotechnical and Geoenvironmental Engineering, 136(3), pp. 477-489 (2009).

76. Motamed, R., Towhata, I., Honda, T., Tabata, K. and Abe, A. "Pile group response to liquefaction-induced lateral spreading: E-Defense large shake table test", Soil Dynamics and Earthquake Engineering, 51, pp. 35-46 (2013). 
77. Hamada, M., Towhata, I., Yasuda, S. and Isoyama, R. "Study on permanent ground displacement induced by seismic liquefaction", Computers and Geotechnics, 4(4), pp. 197-220 (1987).

78. Motamed, R., Sesov, V., Towhata, I. and Anh, N.T. "Experimental modeling of large pile groups in sloping ground subjected to liquefaction-induced lateral flow: 1-G shaking table tests", Soils and Foundations, 50(2), pp. 261-279 (2010).

79. JRA, Seismic Design Specifications for Highway Bridges, Japan Road Association, English version, Prepared by Public Works Research Institute (PWRI) and Ministry of Land, Infrastructure and Transport, Tokyo, Japan (2002).

80. Haeri, S.M., Torabi, H., Kavand, A., Rahmani, I. and Asefzadeh, A. "Evaluation of the effect of lateral spreading on single piles, using shake table test", The 4th International Conference on Geotechnical Engineering and Soil Mechanics, Tehran, Iran (2010a).

81. Haeri, S.M., Kavand, A., Rahmani, I. and Torabi, H. "1-g shaking table model test on single piles response to liquefaction-induced lateral spreading", The 4 th International Conference on Geotechnical Engineering and Soil Mechanics, Tehran, Iran (2010b).

82. Haeri, S.M., Asefzadeh, A., Kavand, A. and Rahmani, I. "Evaluation of the response of $2 \times 2$ piles to liquefaction induced lateral spreading using large scale shake table testing", 6th National Congress on Civil Engineering, Semnan, Iran ( 2011).

83. Haeri, S.M., Kavand, A., Rahmani, I. and Torabi, H. "Response of a group of piles to liquefaction-induced lateral spreading by large scale shake table testing", Soil Dynamics and Earthquake Engineering, 38, pp. $25-45$ (2012g).

84. Haeri, S.M., Kavand, A. and Asefzadeh, A. "Large scale $1-\mathrm{g}$ shake table model test on the response of a stiff pile group to liquefaction induced lateral spreading", Proceedings of the 18th International Conference on Soil Mechanics and Geotechnical Engineering, Paris (2013b).

85. Kavand, A., Haeri, S.M., Asefzadeh, A., Rahmani, I., Ghalandarzadeh, A. and Bakhshi, A. "Study of the behavior of pile groups during lateral spreading in medium dense sands by large scale shake table test", International Journal of Civil Engineering, 12(3), Transaction B: Geotechnical Engineering, pp. 374-391 (2014c).

86. Kavand, A., Haeri, S.M., Raisianzadeh, J., Padash, H. and Rahmani, I. "Evaluation of seismic performance of an existing dolphin-type berth subjected to liquefaction induced lateral spreading by large scale shake table test", The 11th International Conference on Coasts, Ports and Marine Structures (ICOPMAS 2014) Tehran, Iran ( 2014d).

87. Kavand, A., Haeri, S.M., Raisianzadeh, J., Padash, H., Rahmani, I. and Bakhshi, A. "Evaluation of performance of an existing port structure under liquefaction induced lateral spreading by large scale shake table test", Second European Conference on Earthquake Engineering and Seismology (2ECEES) (2014e).

88. BHRC, "Iranian code of practice for seismic resistant design of buildings-standard No. 2800", Iranian Building Codes and Standards, 4th Ed., Prepared by Road, Housing and Urban Development Research Center, Iran (2014).

89. Anastasopoulos, I., Gerolymos, N., Gazetas, G. and Bransby, M.F. "Simplified approach for design of raft foundations against fault rupture. Part I: free-field", Earthquake Engineering and Engineering Vibration, 7(2), pp. 147-163 (2008).

90. Wells, D.L. and Coppersmith, K.J. "New empirical relationships among magnitude, rupture length, rupture width, rupture area, and surface displacement", Bulletin of the Seismological Society of America, 84(4), pp. 974-1002 (1994).

91. Bray, J.D. "Developing mitigation measures for the hazards associated with earthquake surface fault rupture", In Workshop on Seismic Fault-Induced Failures-Possible Remedies for Damage to Urban Facilities, University of Tokyo Press, pp. 55-79 (2001).

92. Bransby, M.F., Davies, M.C.R. and Nahas, A.E. "Centrifuge modelling of normal fault-foundation interaction", Bulletin of Earthquake Engineering, 6(4), pp. 585-605 (2008).

93. Ulusay, R., Aydan, Ö. and Hamada, M. "Faulting and fault-induced damages and disasters: the behaviour of structures built on active fault zones: examples from the recent earthquakes of turkey", Structural Engineering/Earthquake Engineering, 19(2), pp. 149S-167S (2002).

94. Bray, J.D. and Kelson, K.I. "Observations of surface fault rupture from the 1906 earthquake in the context of current practice", Earthquake Spectra, 22(S2), pp. 69-89 (2006).

95. Bray, J.D. "Developing mitigation measures for the hazards associated with earthquake surface fault rupture", In Workshop on Seismic Fault-Induced Failures-Possible Remedies for Damage to Urban Facilities, University of Tokyo Press, pp. 55-79 (2001).

96. Kelson, K.I., Kang, K.H., Page, W.D., Lee, C.T. and Cluff, L.S. "Representative styles of deformation along the Chelungpu fault from the 1999 Chi-Chi, Taiwan (2001). earthquake: geomorphic characteristics and responses of man-made structures", Bulletin of the Seismological Society of America, 91(5), pp. 930-952 (2001).

97. Anastasopoulos, I., Callerio, A., Bransby, M.F., Davies, M.C.R., El Nahas, A., Faccioli, E., Gazetas, G., Masella, A., Paolucci, R. and Pecker, A. "Numerical analyses of fault-foundation interaction", Bulletin of Earthquake Engineering, 6(4), pp. 645-675 (2008).

98. Anastasopoulos, I., Gazetas, G., Bransby, M.F., Davies, M.C. and El Nahas, A. "Normal fault rupture interaction with strip foundations", Journal 
of Geotechnical and Geoenvironmental Engineering, 135(3), pp. 359-370 (2009).

99. Blumetti, A.M., Guerrieri, L., Brustia, E., Caputo, A.M., Poddighe, S. and Vittori, E. "Surface faulting risk in Italy from capable faults and urban sprawl data", In Geophysical Research Abstracts, 9, p. 09440 (2007)

100. Anastasopoulos, I. and Gazetas, G. "Foundationstructure systems over a rupturing normal fault, Part I: observations after the Kocaeli 1999 earthquake", Bull. of Earthquake Engineering, 5, pp. 253-275 (2007a).

101. Anastasopoulos, I. and Gazetas, G. "Foundationstructure systems over a rupturing normal fault, Part II: Analysis of the Kocaeli case histories", Bull. of Earthquake Engineering, 5, pp. 277-301 (2007b).

102. http://www.ce.washington.edu/liquefaction/html/ what/what1.html

103. http://www.ce.washington.edu/liquefaction/html/ quakes/kobe/kobe.html

\section{Biographies}

S. Mohsen Haeri was born in 1954 in Tehran. Since 1992, he has been a Professor of Civil Engineering, Geotechnical Division, at Civil Engineering Department of Sharif University of Technology, Tehran; and since 2004, he has been the Director of Geotechnical Engineering Studies and Research Center (GESRC) of Sharif University of Technology. He also served as the Past Chairman of the Civil Engineering Department (2011-2013) and Ex-Director of the Earthquake Engineering Research Center at Sharif University of Technology (1997-2003), where he completed and established the Earthquake Simulator Laboratory, with a large scale $4 \mathrm{mx} 4 \mathrm{~m}$ 3DOF system Shake Table.

Professor Haeri received his MSc graduate in Civil Engineering from Technical Faculty, University of Tehran, Iran (1977); and in Geotechnical Engineering from University of Illinois at Urbana-Champaign, USA (1979). He also received his PhD degree in Earthquake Geotechnical Engineering from Imperial College of University of London, UK (1988).
His Research Interests are fairly wide and mainly stays in the following subjects: Soil characterization including unsaturated, cemented, collapsible and gravelly soils under static and dynamic loadings, earthquake geotechnical engineering (liquefaction, lateral spreading, landslide and local site effects including microzonation), static and dynamic behavior of earth and rockfill dams with especial focus on dynamic behavior of CFRD, physical modeling of geotechnical structures including piles under lateral spreading, soil structure interaction, deep excavations and related retaining structures, and implementation of soft computing in geotechnical engineering problems.

Professor Haeri has published or contributed in writing 9 books in Farsi and has also published about 40 refereed international and national journal papers, more than 12 nationally and internationally keynote or theme lectures, and more than 120 international and national conference papers. He has taught more than 10 different courses, supervised more than 10 $\mathrm{PhD}$ students in Geotechnical Engineering and one in engineering geology, and more than 85 MS thesis.

Professor Haeri is active in both academic era, and Scientific and Technical Societies and committees including Iranian Geotechnical Society. Also, he has been involved in different committees for preparation of Code of Practice for Engineers including the Iranian Code for Earthquake Resistant Design of Buildings (Standard 2800) for a long time. In addition to his academic affairs, Professor Haeri is very active in advising and consulting the industry, being Head and Member of Panel of Experts for many important projects including the highest constructed and under design arch dams in Iran (e.g. Karun IV Dam HPP, $230 \mathrm{~m}$ high, $1000 \mathrm{MW}$ Power Plant, constructed and under operation, and Bakhtiari Dam, 315m High, 2000 MW power plant, under design, etc.), and being involved in design, supervision and advise of very difficult and deep excavations in the city of Tehran, and other cities, and many other professional and research projects. 